\title{
Tomasz R. Szymczyński, Horyzonty sporu wokót istoty zjawiska deficytu demokratycznego w Unii Europejskiej, Dom Wydawniczy ELIPSA, Warszawa 2013, ss. 397.
}

Tomasz R. Szymczyński w swoich licznych publikacjach podejmował tematykę związaną z szeroko rozumianą Unią Europejską, koncentrując się na aspektach ekonomicznych, politycznych czy społecznych. Nieobcą problematyką są dla Autora zagadnienia teorii demokracji czy integracji europejskiej. Właśnie temu zagadnieniu poświęcił on swoją ostatnią publikację, która jest przedmiotem niniejszej recenzji. Zjawisko deficytu demokracji w Unii Europejskiej jest tematyką podejmowaną przez zachodnich autorów, jednak na gruncie polskim, jak również zagranicznym, brakuje monografii podejmującej w innowacyjny sposób ww. zjawisko. Autor recenzowanej publikacji podjął się tego intelektualnego wyzwania i ze swego obowiązku wywiązał się w sposób bardzo dobry. Recenzowana książka składa się z sześciu rozdziałów, wstępu, zakończenia oraz obszernej bibliografii. Autor już w bardzo dobrze napisanym Wstęie zaznacza, iż zarówno Unia Europejska, jak i demokracja są to pojęcia, które można interpretować na wiele sposobów. Fakt ten implikuje szereg wyzwań stojących przed badaczem, by z jednej strony nie utonąć w mnogości możliwych znaczeń opisywanych zjawisk oraz by z drugiej strony nie potraktować opisywanego zjawiska powierzchownie. Autor, by uniknąć wspomnianych zagrożeń wykorzystał w swojej pracy metodę hermeneutyczną Hansa-Georga Gadamera. W publikacji postawił Tomasz R. Szymczyński cztery pytania badawcze oraz wyróżnił cztery cele pracy, które zostały wyczerpująco wyjaśnione i zrealizowane w dalszej części pracy. Rozdział pierwszy został podzielony przez Autora na osiem części, które spaja wprowadzenie do danej problematyki oraz podsumowanie. Podobny zabieg zastosowany został również w przypadku pozostałych rozdziałów, co moim zdaniem ułatwia lekturę książki, czyniąc recenzowaną monografię bardziej przejrzystą. W rozdziale pierwszym Tomasz R. Szymczyński przedstawia sylwetkę Hansa-Georga Gadamera, słusznie zauważając, iż geniusz niemieckiego filozofa i filologa może być czynnikiem paradoksalnie utrudniającym interpretacjęjego prac. Autor analizuje następnie czym jest tzw. rozum hermeneutyczny oraz jego trzy charaktery: praktyczny, dziejowy oraz językowy. Tomasz R. Szymczyński słusznie kontestuje, iż potencjał skupiony w pracach Hansa-Georga Gadamera nie jest obecnie wystarczająco wykorzystany w dyskusji dotyczącej procesu integracji europejskiej. Rozdział drugi, podzielony na dziesięć części, poświęcony został omówieniu źródeł współczesnych teorii demokracji. Autor w szczegółowy sposób charakteryzuje kolejnych autorów koncentrując się przede wszystkim na koncepcjach zrodzonych w antycznych Atenach. Tomasz R. Szymczyński słusznie zauważa bowiem, iż wszelka próba dokonania syntezy dorobku autorów niesie ze sobą potencjalne zagrożenie pominięcia niektórych teorii. W dalszej części rozdziału Autor charakteryzuje istotne dla prowadzonej narracji pojęcia mitu i logosu oraz ukazuje ich wzajemną relację. Ważnym elementem opisywanej części publikacji jest dokonana charakterystyka pojęcia politei zarówno u Platona, jak i u Arystotelesa.

Po dokonaniu charakterystyki dorobku filozofów antycznej Grecji, Tomasz R. Szymczyński analizuje myśl republikańską. Należy zgodzić się z Autorem, iż niemożliwym jest omówienie jej idei bez odwołania się do greckiej spuścizny. Autor recenzowanej publikacji opisuje następnie genezę oraz znaczenie demokracji przedstawicielskiej, która rozwinęła się w XIX wieku. Współczesne teorie demokracji stanowią temat trzeciego, składającego się z dziewięciu części, rozdziału. Autor scharakteryzował w nim przejście z klasycznych teorii demokracji do koncepcji współczesnych. Jako moment przełomowy owej zmiany Tomasz R. Szymczyński wybrał moment śmieci Fryderyka Nietzschego w 1900 roku. Autor zaznaczył dalej, iż owa współczesność charakteryzować będzie się nowym zjawiskiem, jakim było pojawienie się społeczeństwa oraz kultury masowej. W dalszej części rozdziału omówione zostały główne myśli takich autorów, jak Max Weber, Joseph A. Schumpeter, Robert A. Dahl, Giovanni Sartori oraz Pierre Bourdieu. Zastosowanie tak szerokiego spektrum umożliwiło Autorowi poznanie rozmaitych 
narzędzi badawczych, które następnie umożliwiły mu zrealizowanie celów pracy. Istotne miejsce w omawianej części poświęcił Autor również roli języka oraz jego trzem cechom: linearności, dychotomiczności i substancjalności. Rozdział czwarty poświęcony został relacji współczesnych teorii integracji europejskiej z demokracją. W sześciu kolejnych częściach Autor dokonuje charakterystyki klasycznych teorii integracji europejskiej, rozwiązań zaproponowanych przez Jeana Monneta oraz teorii współczesnych. Tomasz R. Szymczyński słusznie kontestuje, iż wszelkie próby dokonania zjednoczenia Europy posiadają bogatą tradycję historyczną, w której nieraz próby ujęcia teoretycznego integracji służyły partykularnym interesom danych państw. Autor monografii szczegółowo omawia następnie poszczególne podejścia teoretyczne. Ważnym elementem jest osadzenie ich w perspektywie historycznej, wskazując równocześnie na ich źródła. Tomasz R. Szymczyński zauważa także, iż zagadnienie demokracji nie było głównym przedmiotem zainteresowania twórców klasycznej teorii integracji europejskiej. Tematem piątego rozdziału uczynił Autor kwestię deficytu demokracji w Unii Europejskiej w perspektywie prawnej i tożsamościowej. Wzajemne oddziaływanie prawa i tożsamości posiada istotny zdaniem Tomasza R. Szymczyńskiego wpływ na problem deficytu demokratycznego. Autor publikacji przyjął w omawianym rozdziale optykę Dimitrisa Chryssochoou porządkującą problematykę deficytu demokratycznego z uwzględnieniem odmiennych punktów widzenia, tj. prawa oraz przestrzeni społeczno-psychologicznej. W dalszej części rozdziału Autor skoncentrował się na źródłach prawa Unii Europejskiej jako instytucjonalno-prawnych czynnikach wpływających na deficyt demokratyczny. Następnie Autor ukazał i omówił perspektywę społeczno-psychologiczną koncentrując się na zjawisku oddalania obywateli Unii od europejskiego procesu integracji. Autor w wyczerpujący sposób scharakteryzował obie perspektywy oraz odniósł je, w dalszej części rozdziału, do problematyki dylematu między rozszerzeniowym i pogłębieniowym wymiarem procesu integracji europejskiej. Ostatni, szósty rozdział stanowi analizę zjawiska deficytu demokratycznego w Unii Europejskiej z perspektywy hermeneutycznej. Autor słusznie zaznaczył, iż badanie tak złożonego podmiotu współczesnych stosunków międzynarodowych generuje szereg problemów i wyzwań. Sprowadzają się one do podstawowego dylematu przyjęcia perspektywy całościowej bądź fragmentarycznej. Autor ukazuje następnie zalety przyjęcia metody hermeneutycznej, która w przeciwieństwie do analitycznej umożliwia zastosowanie wielowymiarowej perspektywy. Tomasz R. Szymczyński charakteryzuje w dalszej części rozdziału główne dylematy dyskusji dotyczącej deficytu demokratycznego w Unii Europejskiej. Ważne miejsce w przyjętych przez Autora rozważaniach stanowi relacja między filozofią nauki a socjologią wiedzy oraz rola komunikacji w procesie legitymizacji władzy. Ostatnią częścią recenzowanej publikacji jest podsumowanie. Autor odpowiedział w nim na pytania badaweze postawione we wstępie pracy oraz zwrócił uwagę na obszary szczególnie istotne w kontekście dalszych procesów integracyjnych. Stanowić mogą one temat prac kolejnych badaczy podejmujących w swych rozważaniach problematykę deficytu demokratycznego w Unii Europejskiej. Publikacja Tomasza R. Szymczyńskiego stanowi bardzo istotny wkład w toczącą się dyskusję nad problematyką deficytu demokratycznego w Unii Europejskiej, która w polskiej literaturze jest praktycznie nieobecna. Wnikliwość analizy przeprowadzonej przez Autora, znajomość przeogromnej literatury oraz wynikająca $z$ jej lektury refleksja powodują, iż omawiana publikacja jest $\mathrm{z}$ całą pewnością godną polecenia.

\section{RAFAE KAMPROWSKI}

